\title{
Effect of Alsi/Flaxseed (Linum Usitatissimum) on Different Physiological and Biochemical Metabolic Derangements in Metabolic Syndrome in Northwest Zone of Rajasthan
}

\author{
*Sanjay Garg, *Surendra Kumar, *Suresh K Gajraj, *Ishan Patel, *Akhil Gupta, *Ashish \\ Chakranarayan \\ *Department of Physiology, SPMC, Bikaner, Rajasthan (Resident of physiology \\ *Department of Medicine, SPMC, Bikaner, Rajasthan (Professor of medicine) \\ *Department of Medicine, SPMC, Bikaner, Rajasthan (Resident of medicine) \\ *Department of Medicine, SPMC, Bikaner, Rajasthan (Resident of medicine) \\ *Department of Medicine, SPMC, Bikaner, Rajasthan (Resident of medicine) \\ *Department of Medicine, SPMC, Bikaner, Rajasthan (Resident of medicine)
}

*Corresponding Author: Surendra Kumar, Professor, Department of Medicine, SPMC, Bikaner, Rajasthan.

\begin{abstract}
Aim: To study the effect of Flaxseed therapy on various metabolic derangements of metabolic syndrome and its role as alternative or adjunctive therapy.

Material \& Methods: In this randomized control trial, 100 patients of metabolic syndrome attending the Diabetes Care and Research Center of S. P. Medical College \&P.B.M. Hospital, Bikaner were randomly selected. The selected patients were divided randomly into two groups comprising of 50 patients each. Control group was given conventional treatment only. Study group, besides conventional treatment was given Alsi/Flaxseeds.
\end{abstract}

Observations: In our study we found that flaxseed therapy has good glycemic control, both fasting blood sugar and glycosylated haemoglobin highly significant in study group $(p<0.001)$. Systolic and diastolic blood pressure improved, highly significant in study group after flaxseed therapy $(p<0.001)$. Lipid profile improved, highly significant in study group after flaxseed therapy ( $p<0.001)$.

Conclusion: Flaxseed therapy can be used as an adjuvant with diet and medicines in management of various metabolic derangements of metabolic syndrome.

Keywords: flaxseed, blood glucose, blood pressure, lipid profile, Body Mass Index.

\section{INTRODUCTION}

Metabolic syndrome (MS) is the most common disease today, representing one of the major public health problems of the century and its incidence has gradually increased over time ${ }^{1,2}$. It is estimated that one quarter of the world population has $\mathrm{MS}^{3,4}$.

The metabolic syndrome (syndrome $\mathrm{X}$, insulin resistance syndrome) consists of constellation of metabolic abnormalities that confer increased risk of cardiovascular disease (CVD) and diabetes mellitus (DM).The major features of the metabolic syndrome includes: Central obesity, Hypertriglyceridemia, Low HDL Cholesterol, Hyperglycemia and Hypertension ${ }^{5}$.
Preventive measures and therapeutic strategies, such as changes in lifestyle including nutrition interventions and physical activity, are the possible ways to avoid the onset of metabolic syndrome 6 . Flax plant is the most abundant source of omega-3 ( $\alpha$-linolenic acid, ALA) and can be easily found, as well as being cheaper than the fish oil, which is also the source of this fatty $\operatorname{acid}^{7}$. $\alpha$-linolenic acid is an essential polyunsaturated fatty acid dependent on foods ingestion that contain it, since it cannot be synthesized by the human body. From $41 \%$ of the total fat present in flaxseed oil, 57\% come from the omega 3, which has anti-inflammatory, anti-thrombotic, and anti-arrhythmic properties ${ }^{8}$. Based on the results of clinical trials, epidemiological investigations, and 
Effect of Alsi/Flaxseed (Linum Usitatissimum) on Different Physiological and Biochemical Metabolic Derangements in Metabolic Syndrome in Northwest Zone of Rajasthan

experimental studies, it has been suggested that ALA intake has a high impact on cardiovascular disease (CVD), For this reason, the use of flaxseed has been advocated in the prevention of heart disease and therefore the MS, which is currently the most common metabolic disease among these patients ${ }^{9}$. Flaxseed also contains other components with beneficial effects on health, such as dietary fiber and lignans, from which the Secoisolariciresinol diglucoside (SDG) is the main ${ }^{10}$. This oilseed is considered a functional food, producing metabolic and physiological health benefits, in addition to its nutritional properties. Its consumption has been increasing progressively because it is a popular alternative to pharmacological treatment. These effects are manifested as improvement in lipid profile, reducing the development of type 1 and type 2 diabetes mellitus, reducing blood pressure, and controlling weight gain.

\section{MATERIAL AND METHODS}

This randomised control trial study was conducted in Sardar Patel Medical College, Bikaner in 2015-16. Patients were selected from the Diabetes Care and Research Center as well as OPD of General Medicine of P.B.M. Hospital, Bikaner. One hundred patients of metabolic syndrome were randomly selected and divided randomly into two groups comprising of 50 patients each. Patients suffering from liver disease, arthritis, pulmonary tuberculosis, malabsorption, alcoholism, asthma, seizure disorder, pregnant and breast feeding women and any other disease in addition to metabolic syndrome and non-cooperative patients were excluded from the study.

Before starting flaxseeds baseline parameters were taken for every patients i.e. body mass index, waist hip ratio, fasting blood sugar, blood pressure and lipid profile. Patients were evaluated weekly for Body Mass Index, Waist Hip Ratio, Fasting Blood Sugar and Blood Pressure. After three months besides above test lipid profile were also estimated. In group 1 patients were given conventional treatment only and will serve as the control group. In group 2 patients besides conventional treatment were given Alsi/ Flaxseeds and serve as the study group. Patients included in the study group were asked to take whole flaxseed 3 to 4 table spoon daily to benefit from the fiber \& Omega-3 fatty acid.

\section{Ethical Consideration}

Ethical clearance of this study was approved from the regional Ethical Review Committee (ERC). Data regarding the age and sex was recorded in predesigned forms.

\section{RESULT}

This randomized control trial study was conducted in Sardar Patel Medical College, Bikaner. Out of the total 100 patients, 50 were in control group (Group 1) and 50 were in study group (Group 2). Within the control group 37 were males and 13 were female patients. In the study group 19 were males and 31 were female patients. The mean age of the subjects in control group was $52.46 \pm 12.73$ years and in study group was $53.88 \pm 8.76$ years. All patients evaluated for body mass index, waist hip ratio, fasting blood sugar, blood pressure and lipid profile. Patients were evaluated weekly for Body Mass Index, Waist Hip Ratio, Fasting Blood Sugar and Blood Pressure. After three months besides above test lipid profile were also estimated.

The comparison between means of the difference of the pre and post treatment of control and study groups for different physiological and biochemical parameters was done. Highly significant differences were found in all the parameters $(\mathrm{p}<0.001)$ except BMI and WHR where no difference was observed because in study group between 0 to 3 months no mean difference was found. (Table 3 )

The pretreatment mean BMI in control group was $31.14 \pm 2.88 \mathrm{~kg} / \mathrm{m}^{2}$ and in study group was $32.71 \pm 5.35 \mathrm{~kg} / \mathrm{m}^{2}$. After treatment mean BMI in control group was $31.14 \pm 2.88 \mathrm{~kg} / \mathrm{m}^{2}$ and in study group was $32.71 \pm 5.35 \mathrm{~kg} / \mathrm{m}^{2}$. The difference of BMI in two groups was statistically insignificant $(\mathrm{p}=0.071)$.The pretreatment mean WHR in control group was $0.96 \pm 0.02$ and in study group $0.94 \pm 0.09$. This difference was statistically insignificant $\quad(p=0.098)$. No significant difference observed after three month treatment.

The pretreatment mean systolic Blood Pressure in control group was $150.48 \pm 11.43 \mathrm{mmHg}$ and in study group, mean systolic BP was $142.60 \pm 12.49 \mathrm{mmHg}$. After treatment the mean systolic Blood Pressure in control group was $147.12 \pm 11.66 \mathrm{mmHg}$ and in study group mean systolic BP was $136.76 \pm 11.03 \mathrm{mmHg}$. The difference was statistically highly significant $(\mathrm{p}<0.001)$. The mean diastolic BP in control 
group was $94.24 \pm 6.85 \mathrm{mmHg}$ no significant difference was observed after three month. Whereas In study group before alsi supplement mean diastolic BP was $89.52 \pm 7.80 \mathrm{mmHg}$ and after alsi treatment the mean diastolic BP was $89.72 \pm 7.41 \mathrm{mmHg}$. The difference was statistically significant $(\mathrm{p}=0.002)$.

The pretreatment mean fasting blood sugar in control and study groups were $192.08 \pm 40.64 \mathrm{mg} / \mathrm{dl}$ and $169.04 \pm 46.01 \mathrm{mg} / \mathrm{dl}$ respectively. After three month the mean fasting blood sugar in control and study groups were $182.12 \pm 38.20 \mathrm{mg} / \mathrm{dl}$ and $149.58 \pm 44.97 \mathrm{mg} / \mathrm{dl}$ respectively. The difference was statistically highly significant $(\mathrm{p}<0.001)$. Initially the mean $\mathrm{HbA}_{1} \mathrm{C}$ in control and study groups were $8.07 \pm 1.74 \%$ and $7.28 \pm 1.53 \%$. The mean $\mathrm{HbA}_{1} \mathrm{C}$ in control and study groups after three month were $7.98 \pm 1.72 \%$ and $7.02 \pm 1.48 \%$. The difference was statistically significant $(\mathrm{p}=0.003)$.

Mean total cholesterol in control and study groups were $173.43 \pm 39.35 \mathrm{mg} / \mathrm{dl}$ and $180.04 \pm 43.60 \mathrm{mg} / \mathrm{dl}$ respectively. After three month Mean total cholesterol in control and study groups were $171.20 \pm 38.80 \mathrm{mg} / \mathrm{dl}$ and $165.15 \pm 39.98 \mathrm{mg} / \mathrm{dl}$ respectively. The difference was statistically insignificant $(\mathrm{p}=0.445)$.

Mean Triglyceride in control and study groups were $162.59 \pm 78.51 \mathrm{mg} / \mathrm{dl}$ and $142.79 \pm 47.31$ $\mathrm{mg} / \mathrm{dl}$. After three month mean Triglyceride in control and study groups were 156.13 \pm 56.52 $\mathrm{mg} / \mathrm{dl}$ and $134.73 \pm 41.44 \mathrm{mg} / \mathrm{dl}$ respectively and the difference was statistically significant $(\mathrm{p}=0.033)$.

Initially mean HDL Cholesterol in control and study groups were $48.99 \pm 19.35 \mathrm{mg} / \mathrm{dl}$ and $49.47 \pm 20.74 \mathrm{mg} / \mathrm{dl}$ respectively. After three months mean HDL Cholesterol in control and study groups were $49.17 \pm 19.51 \mathrm{mg} / \mathrm{dl}$ and $52.63 \pm 21.14 \mathrm{mg} / \mathrm{dl}$ respectively. The difference was statistically insignificant ( $\mathrm{p}=0.397$ ).

Mean LDL cholesterol in control and study groups were $91.92 \pm 40.20 \mathrm{mg} / \mathrm{dl}$ and $102.01 \pm 37.84 \mathrm{mg} / \mathrm{dl}$ initially. After treatment Mean LDL cholesterol in control and study groups were $90.23 \pm 39.34 \mathrm{mg} / \mathrm{dl}$ and $86.74 \pm 35.54 \mathrm{mg} / \mathrm{dl}$ respectively. The difference was statistically insignificant $(\mathrm{p}=0.642)$.
Initial mean VLDL in control and study groups were $32.52 \pm 15.70 \mathrm{mg} / \mathrm{dl}$ and $28.56 \pm 9.46 \mathrm{mg} / \mathrm{dl}$ respectively. After treatment mean VLDL in control and study groups were $31.23 \pm 11.30$ $\mathrm{mg} / \mathrm{dl}$ and $26.95 \pm 8.29 \mathrm{mg} / \mathrm{dl}$ respectively. The difference was statistically significant $(\mathrm{p}=0.033)$.

\section{DISCUSSION}

The pathogenesis of metabolic syndrome and potential causes suggests that plant FLAX SEED (Linum usitatissimum) polyphenols might be useful as a treatment. High omega 3 fatty acids, lignans, mucilage (gum) content are being actively studied as potential treatments for components of the metabolic syndrome.

Flax seed is one of the richest source of the plant based omega 3 fatty acid, alpha linolenic acid (ALA).ALA is metabolized to eicosapentaenoic acid (EPA), which may replace arachidonic acid in membrane phospholipids. Ingestion of flaxseed oil may alter the generation of eicosanoids, procoagulant activity and other membrane-dependent responses and exert anti-allergic, antiatherosclerotic, anti-arrhythmic effects ${ }^{11}$. Also have predominant anti-aggregating and vasodialating action, with respect to eicosanoids with a predominant thrombotic effect. So dietary ALA has been associated with a lower rate of fatal and nonfatal coronary events ${ }^{12}$.

Dyslipidemia is documented as a major risk factor responsible for the development of atherosclerosis and cardiovascular disease $\mathrm{e}^{13}$. In the year 2009, Bassett et $\mathrm{al}^{14}$ studied that consuming flaxseed daily can modestly reduce circulating total cholesterol and LDL cholesterol in hypercholesterolemic patients.

In the year 2015, Prasad ${ }^{15}$ also found that Secoisolariciresinol diglucoside (SDG) isolated from flaxseed inhibit the production of oxygen radicals by polymorphonuclear leukocytes was associated with a decrease in serum cholesterol, LDL, and lipid peroxidation product and an increase in HDL.

In our study we found that lipid profile improved significantly in study group after flax seed therapy. So our results are consistent with the above mentioned studies.

High blood pressure is a silent killer and it influences other body parts and their functions.In the year 2014, Caligiuri et $\mathrm{al}^{16}$ 
Effect of Alsi/Flaxseed (Linum Usitatissimum) on Different Physiological and Biochemical Metabolic Derangements in Metabolic Syndrome in Northwest Zone of Rajasthan

studied that Plasma $\alpha$-linolenic acid increased with ingestion of flaxseed and was inversely associated with blood pressure. Oxylipins derived from polyunsaturated fatty acids regulate vascular tone. In our study we found that systolic and diastolic blood pressure improved significantly in study group after flaxseed therapy.

Diabetes mellitus is the most common endocrine disorder that affects more than 194 million people worldwide. Flaxseed has been reported to possess a variety of medicinal properties including hypoglycaemic effect. Djousse et $\mathrm{al}^{17}$ found that flaxseed ingestion was associated with insulin secretion and improve glucose use and efficiency.In the year 2000, Prasad ${ }^{18}$ also found that secoisolariciresinol diglucoside (SDG) Flaxseed lignan has been shown to inhibit expression of the phosphoenolpyruvate carboxykinase gene, which codes for a key enzyme responsible for glucose synthesis in the liver. Supplementation of diet of type 2 diabetic with flaxseed reduced fasting blood glucose and glycated haemoglobin. In our study we found that flaxseed therapy had good glycemic control both fasting blood sugar and $\mathrm{HbA}_{1} \mathrm{C}$ improved significantly in study group after flaxseed therapy.

In overweight adolescents, a significant association in terms of derangement among plasma fatty acid composition in metabolic syndrome was identified. Consumption of Flaxseed reduce over-weight ${ }^{19}$. In our study we found that waist Hip ratio and BMI not improved significantly in study group after flaxseed therapy ( $p>0.05$ ) which may be due to shorter duration of study.

\section{CONCLUSIONS}

Flaxseed therapy can be used as an adjuvant with diet and medicines in management of various metabolic derangements of metabolic syndrome. Such studies should be further encouraged as medicinal herbs constitute the corner stone of traditional medicinal practice worldwide. Such studies should be ideally done for a longer duration and large population group to know the changes of BMI and WHR.

Table1. Comparison of different parameters between the groups at pre-treatment

\begin{tabular}{|c|c|c|c|c|c|c|}
\hline \multirow{2}{*}{\multicolumn{2}{|c|}{ Parameters }} & \multicolumn{2}{|c|}{ Control Group } & \multicolumn{2}{|c|}{ Study Group } & \multirow[t]{2}{*}{$\mathbf{p}$} \\
\hline & & Mean & SD & Mean & SD & \\
\hline \multicolumn{2}{|l|}{ BMI } & 31.14 & 2.88 & 32.71 & 5.35 & 0.071 \\
\hline \multicolumn{2}{|l|}{ WHR } & 0.96 & 0.02 & 0.94 & 0.09 & 0.098 \\
\hline \multirow{2}{*}{$\begin{array}{l}\text { Blood } \\
\text { Pressure }\end{array}$} & Systolic & 150.48 & 11.43 & 142.60 & 12.49 & $<0.001$ \\
\hline & Diastolic & 94.24 & 6.85 & 89.52 & 7.80 & 0.002 \\
\hline \multirow{2}{*}{$\begin{array}{l}\text { Glycemic } \\
\text { Control }\end{array}$} & FBS & 192.08 & 40.64 & 169.04 & 46.01 & 0.009 \\
\hline & $\mathrm{HbA}_{1} \mathrm{C}$ & 8.07 & 1.74 & 7.28 & 1.53 & 0.017 \\
\hline \multirow{5}{*}{$\begin{array}{l}\text { Lipid } \\
\text { Profile }\end{array}$} & TC & 173.43 & 39.35 & 180.04 & 43.60 & 0.428 \\
\hline & TG & 162.59 & 78.51 & 142.79 & 47.31 & 0.130 \\
\hline & HDL & 48.99 & 19.35 & 49.47 & 20.74 & 0.906 \\
\hline & LDL & 91.92 & 40.20 & 102.01 & 37.84 & 0.199 \\
\hline & VLDL & 32.52 & 15.70 & 28.56 & 9.46 & 0.130 \\
\hline
\end{tabular}

Table2. Comparison of different parameters between the groups at post-treatment

\begin{tabular}{|c|c|c|c|c|c|c|}
\hline \multirow{2}{*}{\multicolumn{2}{|c|}{ Parameters }} & \multicolumn{2}{|c|}{ Control Group } & \multicolumn{2}{|c|}{ Study Group } & \multirow[t]{2}{*}{$\mathbf{p}$} \\
\hline & & Mean & SD & Mean & SD & \\
\hline \multicolumn{2}{|l|}{ BMI } & 31.14 & 2.88 & 32.71 & 5.35 & 0.071 \\
\hline \multicolumn{2}{|l|}{ WHR } & 0.96 & 0.02 & 0.94 & 0.09 & 0.098 \\
\hline \multirow{2}{*}{$\begin{array}{l}\text { Blood } \\
\text { Pressure }\end{array}$} & Systolic & 147.12 & 11.66 & 136.76 & 11.03 & $<0.001$ \\
\hline & Diastolic & 94.24 & 6.85 & 89.72 & 7.41 & 0.002 \\
\hline \multirow{2}{*}{$\begin{array}{l}\text { Glycemic } \\
\text { Control }\end{array}$} & FBS & 182.12 & 38.20 & 149.58 & 44.97 & $<0.001$ \\
\hline & $\mathrm{HbA}_{1} \mathrm{C}$ & 7.98 & 1.72 & 7.02 & 1.48 & 0.003 \\
\hline \multirow{5}{*}{$\begin{array}{l}\text { Lipid } \\
\text { Profile }\end{array}$} & TC & 171.20 & 38.80 & 165.15 & 39.98 & 0.445 \\
\hline & TG & 156.13 & 56.52 & 134.73 & 41.44 & 0.033 \\
\hline & $\mathrm{HDL}$ & 49.17 & 19.51 & 52.63 & 21.14 & 0.397 \\
\hline & LDL & 90.23 & 39.34 & 86.74 & 35.54 & 0.642 \\
\hline & VLDL & 31.23 & 11.30 & 26.95 & 8.29 & 0.033 \\
\hline
\end{tabular}


Effect of Alsi/Flaxseed (Linum Usitatissimum) on Different Physiological and Biochemical Metabolic Derangements in Metabolic Syndrome in Northwest Zone of Rajasthan

Table3. Comparison between differences of means of anthropometric and biochemical parameters in both groups at 0 to 3 months

\begin{tabular}{|l|l|l|l|l|l|l|}
\hline \multicolumn{2}{|c}{ Parameters } & \multicolumn{2}{c|}{ Control Group } & \multicolumn{2}{c|}{ Study Group } & \multirow{2}{*}{ p } \\
\cline { 3 - 7 } & \multicolumn{1}{|c|}{ Mean } & \multicolumn{1}{c|}{ SD } & \multicolumn{2}{c|}{ Mean } & \multicolumn{1}{c|}{ SD } & \\
\hline BMI & 0.00 & 0.000 & 0.01 & 0.006 & $>0.05$ \\
\hline WHR & 0.00 & - & 0.00 & - & - \\
\hline \multirow{2}{*}{$\begin{array}{l}\text { Blood } \\
\text { Pressure }\end{array}$} & Systolic & 3.36 & 2.57 & 5.84 & 3.38 & $<0.001$ \\
\cline { 2 - 7 } $\begin{array}{l}\text { Glycemic } \\
\text { Control }\end{array}$ & Diastolic & 3.24 & 4.59 & 5.48 & 4.91 & $<0.001$ \\
\cline { 2 - 7 } & FBS & 9.96 & 9.43 & 19.46 & 9.52 & $<0.001$ \\
\hline \multirow{3}{*}{$\begin{array}{l}\text { Lipid } \\
\text { Profile }\end{array}$} & TC & 0.08 & 0.03 & 0.25 & 0.06 & $<0.001$ \\
\cline { 2 - 7 } & TG & 2.23 & 2.97 & 14.89 & 3.61 & $<0.001$ \\
\cline { 2 - 7 } & HDL & 3.86 & 6.59 & 12.06 & 9.44 & $<0.001$ \\
\cline { 2 - 7 } & LDL & 0.17 & 0.30 & 3.16 & 1.41 & $<0.001$ \\
\cline { 2 - 7 } & VLDL & 1.68 & 0.97 & 15.27 & 6.12 & $<0.001$ \\
\hline
\end{tabular}

\section{REFERENCES}

[1] Kanbak G, Akalin A, Dokumacioglo A, Ozcelik E, Bal C. Cardiovascular risk assessment in patients with type 2 diabetes mellitus and metabolic syndrome: role of biomarkers. Diabetes Metab Syndr Clin Res Rev. 2011;5(1):7-11.

[2] Chillarón JJ, Goday A, Pedro-botetb J. Síndrome metabólico, diabetes mellitus tipo $1 \mathrm{y}$ resistencia a la insulina. Med Clin (Barc). 2008;130 (12):466-71.

[3] Paschos P, Paletas K. Non alcoholic fatty liver disease and metabolic syndrome. Hippokratia. 2009;13(1):9-19.

[4] Rana JS, Nieuwdorp M, Jukema JW, Kastelein JJP. Cardiovascular metabolic syndrome - an interplay of, obesity, inflammation, diabetes and coronary heart disease. Diabetes Obes Metab. 2007;9:218-32.

[5] Harrison's Principles of Internal Medicine, McGraw Hill. $17^{\text {th }}$ Edition, Vol. II, 2008; pp 1509-151.

[6] Chen CC, Lin WY, Li CI, Liu CS, Li TC, Chen YT, Yang CW, Chang MP, Lin CC. The association of alcohol consumption with metabolic syndrome and its individual components: the Taichung community health study. Nutr Res. 2012;32:24-9.

[7] Robinson LE, Buchholz AC, Mazurak VC. Inflammation, obesity, and fatty acid metabolism: influence of n-3 polyunsaturated fatty acids on factors contributing to metabolic syndrome. Appl Physiol Nutr Metab. 2007;32:1008-24.

[8] Faintuch J, Horie LM, Barbeiro HV, Barbeiro DF, Soriano FG, Ishida RK, Cecconello I. Systemic inflamation in morbidly obese subjects: response to oral supplementation with alpha-linolenic acid. Obes Surg. 2007;17(3):341-7
[9] Rodriguez-Leyva D, Basset CMC, McCullough R, Pierce GN. The cardiovascular effects of flaxseed and its omega-3 fatty acid, alphalinolenic acid. Can J Cardiol. 2010;26(9):489-96.

[10] Yuan JP, Li X, Xu SP, Wang J. H, Liu X. Hydrolysis kinetics of secoisolariciresinol diglucoside oligomers from flaxseed. J Agric Food Chem. 2008;56(21):10041-7.

[11] Ipatova OM, Prozorovskaia NN, Baranova VS, Guseva DA. Biological activity of linseed oil as the source of omega-3 alpha-linolenic acid. Biomed Khim. 2004; 50(1):25-43.

[12] Nannicini F, Sofi F, Avanzi G, Abbate R, Gensini GF. Alpha-linolenic acid and cardiovascular diseases omega-3 fatty acids beyond eicosapentaenoic acid and docosahexaenoic acid. Minerva Cardioangiol. 2006; 54(4):431-42.

[13] Yusuf PS, Hawken S, Ounpuu S et al. Effect of potentially modifiable risk factors associated with myocardial infarction in 52 countries (the INTERHEART study). case control study. The Lancet 2004; 364:937-952.

[14] Basset CM. Experimental and clinical research findings on the cardiovascular benefits of consuming flax seed. Appl Physiol Nutr Metab. 2009;34(5):965-74.

[15] Prasad K. Reduction of serum cholesterol and hypercholesterolemic atherosclerosis in rabbits by secoisolriciresinol diglucoside isolated from flaxseed. Circulation 1999; 99(10):1355-62.

[16] Caligiuri SP, Aukema HM, Ravandi A, Guzman R, Dibrov E, Pierce GN. Flaxseed consumption reduces blood pressure in patients with hypertension by altering circulating oxylipins via an $\alpha$-linolenic acid-induced inhibition of soluble epoxide hydrolase. Hypertension. 2014; 64(1):53-9.

[17] Djoussé L, Hunt SC, Tang W, Eckfeldt JH, Province MA, Ellison RC. Dietary linolenic 
Effect of Alsi/Flaxseed (Linum Usitatissimum) on Different Physiological and Biochemical Metabolic Derangements in Metabolic Syndrome in Northwest Zone of Rajasthan

acid and fasting glucose and insulin: The National Heart, Lung, and Blood Institute Family Heart Study. Obesity. 2006; 14:295300.

[18] Prasad K, Mantha SV, Muir AD, Westcott ND. Protective effect of secoisolariciresinol diglucoside against streptozotocin-induced diabetes and its mechanism. Mol Cell Biochem 2000; 206: 141-149

[19] Klein-Platat C, Drai J, Oujaa M, Schlienger JL, Simon C. Plasma fatty acid composition is associated with the metabolic syndrome and low-grade inflammation in overweight adolescents. Am J Clin Nutr. 2005; 82:117884.

Citation: Garg S, Kumar S, Gajraj S, Patel I, Gupta A, Chakranarayan A. Effect of Alsi/Flaxseed (Linum Usitatissimum) on Different Physiological and Biochemical Metabolic Derangements in Metabolic Syndrome in Northwest Zone of Rajasthan. International Journal of Research Studies in Medical and Health Sciences. 2017;2(3):21-26.

Copyright: (c) 2017 Kumar S, et al. This is an open-access article distributed under the terms of the Creative Commons Attribution License, which permits unrestricted use, distribution, and reproduction in any medium, provided the original author and source are credited. 